UDC 332

\title{
THE ANALYSIS OF ENTERTAINMENT TAX POTENTIAL ON THE MANAGEMENT OF RECREATIONAL PARKS IN BATU CITY
}

\author{
Enceng \\ Faculty of Law, Social and Political Sciences, University of Terbuka, Indonesia \\ Anggoro Damas Dwi* \\ Faculty of Administrative Science, University of Brawijaya, Indonesia \\ *E-mail: damasdwia@gmail.com
}

\begin{abstract}
One object of regional taxes is entertainment tax. In its development, entertainment tax is very instrumental in an effort to increase regional taxes. The entertainment industry is one potential field to be taxed by the local government. Batu City as one of the tourism destinations in East Java is inseparable from the policies of the local government that is always trying to develop its tourism. Government policies, in improving the tourism sector in Batu City, have an impact on the growth of new business places such as recreation places and other natural attractions. Besides increasing tax revenue from the sector of entertainment tax, the growth of new tourist attractions in Batu City can also improve the economy of the community. It is reported that regional tax revenue becomes the biggest contributor to locally-generated revenue in Batu City from 2014 to 2016. Therefore, the purpose of this study is to analyze the potential of entertainment tax as well as to examine the appropriate strategies in optimizing the entertainment tax on recreational parks and natural attractions in Batu City.
\end{abstract}

\section{KEY WORDS}

Regional tax, tourism, entertainment tax, public service.

Batu City is an autonomous region that has the potential of regional wealth. This potential is empowered through both short-term and long-term development programs. Batu City as one of the tourism destinations is inseparable from the policies of the local government which always tries to develop its tourism system. Government policy in increasing the tourism sector of Batu City has an impact on the growth of new business places, especially in the construction of recreation places and other natural attractions. Not only increasing the tax revenues from entertainment sector, but the growth of new tourist attractions in Batu City can also improve the economy of the community. The following table represents the data of visitors who visit some recreational parks in Batu City from 2014 to 2016.

Table 1 - Visitors of Batu City Recreation Parks in 2014-2016

\begin{tabular}{|c|c|c|c|}
\hline n/n & 2014 & 2015 & 2016 \\
\hline Jatim park 1\&2 & 329,230 & 106,316 & 159,582 \\
\hline Selecta & 702,740 & 788,185 & $1,077,114$ \\
\hline Kusuma Agro & 163,852 & 283,053 & 303,677 \\
\hline Cangar & 255,908 & 211,549 & 229,562 \\
\hline BNS & 271,901 & 248,701 & 253,151 \\
\hline
\end{tabular}

Source: BPS, 2017.

Based on Table 1 and Figure 1 above, it can be known that various types of tourism, both recreational and natural, are one of the magnets for domestic and foreign people to visit Batu City. According to BPS, there were around 2 million visitors in 2016 who visited Batu 
City as tourists. By that, the high level of visitation is one great potential for regional taxes, especially in the sector of entertainment tax.

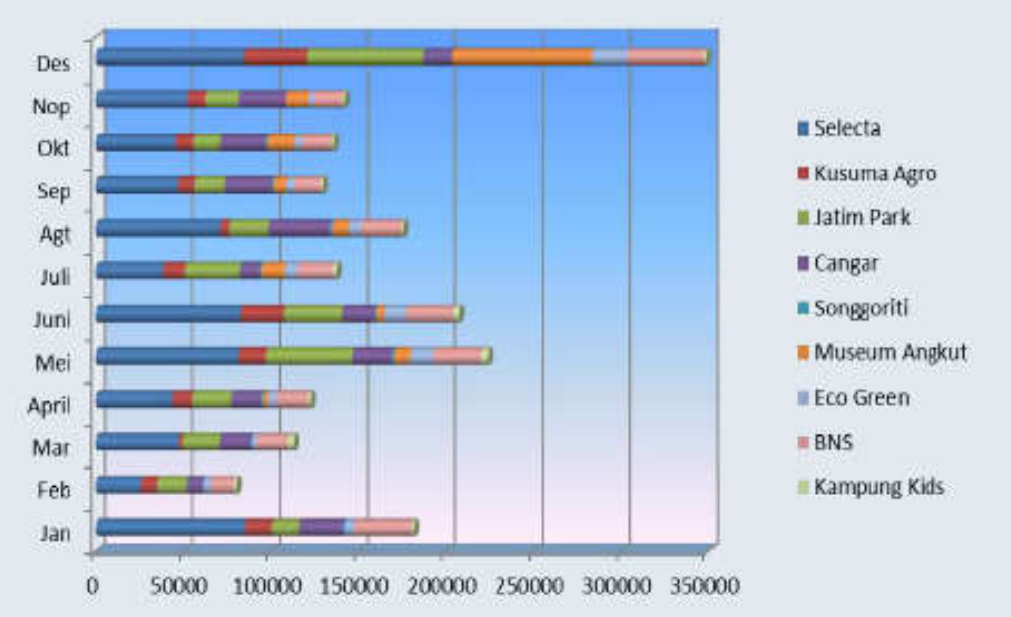

Figure 1 - Visitors of Tourist Attractions in Batu City (Source: BPS, 2017)

In addition to that, the potential of regional taxes can be seen from the economic growth of Batu City which reached $6.61 \%$ in 2016. In that time, the rate was above the average economic growth of East Java (5.5\%). It is known that the most contributors to economic growth in Batu City come from the sector of commerce, agriculture, and service. Locally-generated revenue (Pendapatan Asli Daerah or PAD) also experienced growth every year as shown in the table below:

Table 2 - The Percentage of PAD on Total Revenue of Batu City (2014-2016)

\begin{tabular}{|c|c|c|c|c|c|c|c|c|c|}
\hline \multirow{2}{*}{$\begin{array}{c}\text { Regional } \\
\text { Budget } \\
\text { (Year) }\end{array}$} & \multicolumn{4}{|c|}{ PAD } & \multicolumn{3}{|c|}{ Balancing Fund } & \multirow{2}{*}{$\begin{array}{c}\text { Total } \\
\text { Revenue }\end{array}$} & \multirow{2}{*}{$\begin{array}{c}\text { PAD } \\
\text { Percentage } \\
\text { on Total } \\
\text { Revenue }\end{array}$} \\
\hline & $\begin{array}{l}\text { Regional } \\
\text { Tax }\end{array}$ & $\begin{array}{c}\text { Regional } \\
\text { Retributopm }\end{array}$ & $\begin{array}{c}\text { Management } \\
\text { of Regional } \\
\text { Wealth }\end{array}$ & $\begin{array}{l}\text { Other } \\
\text { Legal } \\
\text { PAD } \\
\end{array}$ & DAU & DAK & $\mathrm{DBH}$ & & \\
\hline \multirow[t]{2}{*}{2014} & $62,8 \mathrm{M}$ & $5,60 \mathrm{M}$ & $2,19 \mathrm{M}$ & $\begin{array}{c}7,69 \\
M\end{array}$ & $\begin{array}{c}412 \\
M\end{array}$ & $\begin{array}{c}30,3 \\
M\end{array}$ & $\begin{array}{l}47 \\
M\end{array}$ & $\begin{array}{c}568,13 \\
M\end{array}$ & $13,7 \%$ \\
\hline & \multicolumn{4}{|c|}{ Total 78,29 M } & \multicolumn{3}{|c|}{ Total 489,84 M } & & \\
\hline \multirow[t]{2}{*}{2015} & $83,7 \mathrm{M}$ & $5,20 \mathrm{M}$ & $2,18 \mathrm{M}$ & $\begin{array}{c}13,15 \\
M\end{array}$ & $\begin{array}{c}413 \\
M\end{array}$ & $\begin{array}{c}41,3 \\
M\end{array}$ & $\begin{array}{l}49 \\
M\end{array}$ & $\begin{array}{c}607.93 \\
M\end{array}$ & $17 \%$ \\
\hline & \multicolumn{4}{|c|}{ Total $104,23 \mathrm{M}$} & \multicolumn{3}{|c|}{ Total 503,7 M } & & \\
\hline \multirow[t]{2}{*}{2016} & $88,7 \mathrm{M}$ & $5,86 \mathrm{M}$ & $2,15 \mathrm{M}$ & $\begin{array}{c}12,77 \\
M\end{array}$ & $\begin{array}{c}480 \\
M\end{array}$ & $\begin{array}{l}93 \\
M\end{array}$ & $\begin{array}{l}66 \\
M\end{array}$ & $\begin{array}{c}749.94 \\
M\end{array}$ & $14,6 \%$ \\
\hline & \multicolumn{4}{|c|}{ Total 109,58 M } & \multicolumn{3}{|c|}{ Total $640,36 \mathrm{M}$} & & \\
\hline
\end{tabular}

Source: Financial Balance Report of Batu City, 2017.

As seen in the Table 2 above, regional tax revenues become the largest contributor to PAD in Batu City during the period of 2014 to 2016. The tax revenue continues to increase every year that is 62,8 million rupiahs in 2014 to 88,7 million rupiahs in 2016. Nevertheless, the increasing PAD is assumed to have not touched the real figure which means that the revenue could be far greater than that. In addition, the balance sheets report from the government of Batu City in 2018 shows that there is a trend of increased tax receivables from 2012 to 2017 . To see it more clearly, the complete data can be seen in Table 3 .

From Table 3, it can be seen that there was an increase in the tax receivables from 2012 to 2017 but not in 2015 that the receivables were decreased by $2.58 \%$ from the previous year. In general, Batu City tax receivables were increased to $13.15 \%$ in 2017 with a total revenue of IDR $65,403,985,323$ billion. The existence of tax potential, especially in entertainment taxes which can be seen from the economic growth, tourism growth, and high entertainment tax receivables is interesting to be examined on how the potential of 
entertainment tax in Batu City is managed, especially in the tourism sector. This can be used as the basis to solve the tourism issues in Batu City as well as to optimize the actual entertainment tax potential in the tourism sector. Therefore, based on the problems above, the researchers wanted to conduct a research with the title of "The Analysis of Entertainment Tax Potential on the Management of Recreational Parks in Batu City".

Table 3 - Tax Receivables of Batu City in 2012-2017

\begin{tabular}{|l|l|l|l|}
\hline Year & Tax Receivables & Change (Delta) & Percentage (\%) \\
\hline 2012 & IDR24,548,456,692,00 & - & - \\
\hline 2013 & IDR41,619,187,791,68 & IDR17,070,731,099,68 & $41.02 \%$ \\
\hline 2014 & IDR54,481,643,270,68 & IDR12,862,455,479,00 & $23.61 \%$ \\
\hline 2015 & IDR53,109,156,526,68 & IDR1,372,486,744,00 & $-2.58 \%$ \\
\hline 2016 & IDR56,804,785,808,68 & IDR3,695,629,282,00 & $6.51 \%$ \\
\hline 2017 & IDR65,403,985,323,00 & IDR8,599,199,514,32 & $13.15 \%$ \\
\hline
\end{tabular}

Source: Financial Balance Report of Batu City, 2018.

\section{LITERATURE REVIEW}

Locally-generated Revenue. Locally-generated Revenue (Pendapatan Asli Daerah or PAD) is the revenue obtained by regions and is collected based on Regional Regulations in accordance with the prevailing laws and regulations. PAD is intended to give an authority to the Local government to fund the implementation of regional autonomy in accordance with the regional potential as an embodiment of decentralization. The granting of autonomy to the regions is directed to accelerate the realization of public welfare through improved services, empowerment, and community participation. Accelerating the improvement of people's welfare is an increase in the human development index which is marked by an increase in health, education, and community income. Besides that, through a broad autonomy, in the strategic environment of globalization, the regions are expected to be able to improve competitiveness by taking into account the principles of democracy, equity, justice, privileges, and specificities as well as the potential and diversity of each region in the system of the Republic of Indonesia.

PAD plays an important role in showing the degree of independence of an area. Higher $P A D$ of a region means that the degree of independence is higher.

The sources of PAD include:

- Regional tax;

- Regional retribution;

- Results of separated regional wealth management;

- Other legitimate regional revenues.

Regional Tax. The theory of development from below argues that people will have more eager to pay taxes to the local government than to the central government because they can easily see the immediate benefits of development in their area (Davey in Anggoro, 2017). Based on this opinion, the importance of regional taxes for regional development can be seen. The benefits of regional taxes also can be directly seen by people in the region.

Bahl and Smoke (2003), argue that:

"local government taxes must be politically acceptable. One rule of thumb is that less visible taxes tend to be more acceptable."

Local government taxes must be politically acceptable. Where the tax in the decision to determine the structure, the amount of the tariff, those who are responsible to pay, and the sanctions must constitute a political agreement between the executive and the legislature as a representation of the people.

According to Davey (1988), local taxes can be interpreted as:

- The taxes collected by the local government with arrangements from the region itself;

- The taxes collected based on national regulations whereas the tariff is determined by the local government; 
- The taxes that are determined and or collected by the local government;

- The taxes collected and administered by the central government but the results of the collection are given to, divided by, or burdened by additional levies from the local government.

Tax Potential. Potential is something that actually exists, only it has not been collected or obtained at hand. It needs specific measures in order to get the desired potential as for an instance, it is necessary to have tax effort to obtain the potential tax (Mahmudi, 2010). To realize all potentials, in this case, is the tax potential, taxpayer awareness needs to be built. Due to the vast potential caused by many factors that influence revenue, it is necessary to identify tax objects more specifically in order to be able to see the real potential. As a result, by multiplying the tax base with the local tax rate, real potential can be found.

Entertainment Tax. Soelarno (1999) defines entertainment as something that can be pleasant for the person who enjoys or consumes it. Entertainment tax is a tax imposed on all entertainment objects collected from fees in a region. Based on the above understanding, the entertainment tax is only imposed on all types of entertainment arrangements that, in order to enjoy the entertainment, are subject to fees. Whereas, the entertainment services that do not charge fees are not subject to entertainment tax. According to Devas (1989), entertainment tax can be seen as one type of tax that is suitable to be classified as a regional tax because amusement park is known for its location so that the local government as an institution that collects taxes can be easily determined. Moreover, the collection fee for entertainment tax occurs due to the establishment of an entertainment.

\section{METHODS OF RESEARCH}

This study uses a qualitative which approach is a process of understanding the proposed social problems in order to analyze the potential of Entertainment Tax in Batu City. The data was collected from primary data and secondary data from books, research reports, and other references such as sources from websites/internet that can be accounted for.

Basically, the calculation of revenue potential can be carried out in two approaches namely macro basis and micro basis. Macro-based calculations can be done through estimation techniques with an econometric regression model that uses macroeconomic variables as proxies while micro-based calculations are performed by conducting surveys and observations of tax objects and subjects and then calculating their revenue potential.

\section{RESULTS OF STUDY}

The Analysis of Entertainment Tax Management Implementation in Tourism Sector. Firstly, the analysis of entertainment tax management in the recreation or tourism sector in Batu City can be seen from how tourism is managed in the city. In the framework of organizing tourism in Batu City which incidentally is the leading sector and is expected to increase the PAD, the government of Batu City has the Regional Regulation number 1 of 2013 concerning Tourism Organizations in which this Regional Regulation is made by the House of Representatives in a mutual agreement with the Mayor. This is important because one of the obligatory functions of the Local Government is mandated by the Law number 32 of 2004 concerning Local Government in conjunction with Government Regulation number 38 of 2007 concerning the Division of Government Affairs between the Central Government, Provincial Government, and Local/Municipal Government that the sub-sector policy of the tourism sector is the granting of city-scale tourism business licenses. In the tourism sector, Batu City seems to have a coaching, supervision, control, and development so that the business opportunities for tourism business actors can be equal and the community as part of the stakeholders still can benefit.

Based on the results of interviews with Informant 1 from the Department of Tourism, one of the tourism developments is in the form of opportunities for business actors who invest in the development of artificial tourism objects such as Jatim Park 1, 2, and 3. Besides that, there is a mix of natural attractions and artificial tourism objects as already established 
in Coban Talun and Coban Rais. This also can be seen in the construction of special objects or interests such as paragliding and outbound. Not only developing tourism, but Informant 1 also explained that the Department of Tourism also active in supervising the object or village that has the potential to be developed. This assistance is carried out in collaboration with the village, Department of Tourism, as well as academics to find the best alternative for their potential development. In terms of funds, the village has an allocation fund that can be used as capital to develop the tourism potential in the region. This kind of mentoring and coaching is expected to increase the tourism potential of Batu City which in turn can provide a multiplier effect such as increasing economic growth, improving the welfare of the surrounding community, reducing poverty, reducing unemployment, contributing to preserving nature and the environment, promoting culture, nurturing a sense of nationality, and strengthening the identity in unity.

This effort adheres to the principles of regional tourism implementation including upholding the religious norms and cultural values as the embodiments of the concept of life in the balance relationship between humans and God, humans, and humans, as well as humans and the environment. It also respects human rights, cultural diversity, local wisdom that benefits the welfare of the people, justice, equality, and proportionality. Moreover, tourism development holds on the principle of maintaining the environmental sustainability, empowering the surrounding communities, as well as maintaining the integration between sectors, regions, and central which incidentally constitute a systemic unit within the framework of regional autonomy and among stakeholders. It is important to note that this development must maintain the universal tourism ethics code and international agreements in the field of tourism and strengthen the integrity of the Republic of Indonesia.

Informant 1 added that tourism development is also done by introducing the existing tourism potential in Batu City through promotions either by making regular annual events or online promotions. The annual event might be in the form of international paragliding competition that is followed by participants from all over the world. On the other hand, the online promotions are done by intensifying promotions through social media such as Instagram, YouTube, Twitter, and websites. The promotions were also conducted by making visits to several cities. The most recent visit is known to be in Tarakan to introduce the tourism potential of Batu City by inviting artists and tourists out of the city. Besides that, the government is also active to have a participation in both local and international exhibitions. Not only that, manual promotion is still done by printing brochures, books, souvenirs, and calendars that are sent to travel agents outside Batu City which also distributed to schools. All of these promotions can increase the level of both domestic and foreign tourist visits. This is evidenced by the data on the level of visits which reached 3,862,712 visitors in 2017 consisting of 3,856,529 domestic tourists and 6,183 foreign tourists.

The second analysis is to look at Batu City's entertainment tax collection system. Informant 2, that is from the Regional Finance Agency of Batu City, explained that the collection is performed by using a self-assessment system. This system explains that taxpayers are given the trust to calculate, pay, and deposit their own tax obligations. This requires the active role of the taxpayers as well as the supervisory role of the tax authorities. The active role of taxpayers' starts from their own tax calculation in which they will continue to pay the taxes by filling in the local tax deposit (Surat Setoran Pajak Daerah or SSPD) based on the proof of deduction or proof of ticket which depends on the type of tax in the service section. After that, the taxpayers will receive a unique number (code) to be used to East Java Bank. Meanwhile, the function of the Regional Finance Agency is a supervisor who provides socialization, supervision, inspection, and collection.

Then, in the third analysis, the researchers used the level of effectiveness of Batu City entertainment tax revenue. According to Devas (1989), one of the benchmarks for regional revenue administration is to calculate the level of effectiveness or tax results (tax effectivity). The following table shows the level of effectiveness of Batu City entertainment tax in 2017. 
Eurasia: Economics \& Business, 7(13), July 2018

DOI https://doi.org/10.18551/econeurasia.2018-07

Table 4 - The Level of Effectiveness of Batu City Entertainment Tax in 2017

\begin{tabular}{|l|l|l|l|l|}
\hline \multirow{2}{*}{ Number } & Regional Tax & Target & Realization & $\%$ \\
\cline { 2 - 5 } & Entertainment Tax & $13,650,000,000,00$ & $14,826,307,547,00$ & 108.62 \\
\hline 1 & Movie/Cinema & $251,653,900,00$ & $311,106,368,00$ & 123.62 \\
\hline 2 & Art/Music/Dance/Fashion Performance & $22,000,000,00$ & $22,700,000,00$ & 103.18 \\
\hline 3 & Exhibition & $11,190,000,000,00$ & $12,293,100,254,00$ & 109.86 \\
\hline 4 & Karaoke & $372,481,950,00$ & $371,797,757,00$ & 99.82 \\
\hline 5 & Circus/Acrobatics/Magic & - & - & - \\
\hline 6 & Motor Racing & - & $3,853,636,00$ & - \\
\hline 7 & Agility Game & $1,710,581,000,00$ & $1,710,755,782,00$ & 100.01 \\
\hline 8 & Massage/Home Reflection & $95,250,000,00$ & $105,578,250,00$ & 110.84 \\
\hline 9 & Fitness center & $8,033,150,00$ & $7,415,500,00$ & 92.31 \\
\hline 10 & Entertainment Tax/Sports Match & - & - & - \\
\hline 11 & VCD rental & - & - & - \\
\hline
\end{tabular}

Source: Regional Finance Agency of Batu City (2018).

Based on the table above, the target of entertainment tax revenue in 2017 is set at IDR $13,650,000,000$ in which the realization happens to be in IDR $14,826,307,547$. This can be said that the overall entertainment tax is effective because the realization of revenue is $108.62 \%$ or greater than the target set. Furthermore, if it is viewed more specifically on the effectiveness of entertainment tax in the recreational sector (2014 to 2017), the figures can be seen in the Table 5 as follows.

Table 5 - The Effectiveness of Entertainment Tax per Recreation Sector in 2014-2017

\begin{tabular}{|c|c|c|c|c|c|}
\hline Number & Year & Object & Target & Realization & $\%$ \\
\hline \multirow{3}{*}{1} & \multirow{3}{*}{2014} & Exhibition & $5,824,000,000,00$ & $4,402,698,611,00$ & $75.6 \%$ \\
\hline & & Art/Music/Dance/Fashion Performance & 0 & $835,000,00$ & 0 \\
\hline & & Agility Game & $10,000,000,00$ & $1,365,866,946,00$ & $13658.6 \%$ \\
\hline \multirow{3}{*}{2} & \multirow{3}{*}{2015} & Exhibition & $5,224,000,000,00$ & $5,697,844,110,00$ & $109 \%$ \\
\hline & & Art/Music/Dance/Fashion Performance & 0 & $2,182,500,00$ & 0 \\
\hline & & Agility Game & $1,305,000,000,00$ & $1,598,522,249,00$ & $122.5 \%$ \\
\hline \multirow{3}{*}{3} & \multirow{3}{*}{2016} & Exhibition & $7,142,886,400,00$ & $7,831,167,654,00$ & $109.6 \%$ \\
\hline & & Art/Music/Dance/Fashion Performance & 0 & 0 & 0 \\
\hline & & Agility Game & $2,079,859,600,00$ & $1,720,062,899,00$ & $82.7 \%$ \\
\hline \multirow{3}{*}{4} & \multirow{3}{*}{2017} & Exhibition & $11,190,000,000,00$ & $12,293,100,254,00$ & $109.9 \%$ \\
\hline & & Art/Music/Dance/Fashion Performance & $22,000,000,00$ & $22,700,000,00$ & $103.2 \%$ \\
\hline & & Agility Game & $1,710,581,000,00$ & $1,710,755,782,00$ & $100 \%$ \\
\hline
\end{tabular}

Source: Regional Finance Agency of Batu City, 2018 (Processed).

Note: in this study, the object of entertainment tax in the tourism sector consisted of Art/Music/Dance/Fashion Performance, Agility Games, and Exhibitions.

Based on the table above, the effectiveness of the entertainment tax in the exhibition sector amounted to $75.6 \%$ in 2014 . This means that it is less effective because the realization of revenues from the exhibition sector was IDR $4,402,698,611$ that is below the set target of IDR 5,824,000,000. Then, there was an increase in 2015 with a $109 \%$ effectiveness level which can be said to be very effective with the realization of IDR $5,697,844,110$ in the target set by IDR 5,224,000,000. The level of effectiveness in 2016 and 2017 is also categorized as very effective $(109.6 \%$ and $109.9 \%)$.

On the other hand, the effectiveness of the object of art/music/dance/fashion performance from 2014 to 2016 was 0\%. This happens because the Regional Finance Agency of Batu City did not set the target for this tourist attraction although there were revenues by IDR 835,000 in 2014 and IDR 2,182,500 in 2015. In 2016, the realization and target were IDR 0 while in 2017, the Regional Finance Agency of Batu City has just set a revenue target of IDR $22,000,000$ with a revenue effectiveness level by $103.2 \%$.

The level of effectiveness of agility games from 2014-2017 can be said to be fluctuating. In 2014, 2015, and 2017 the revenue realization was greater than the target set so that it could be categorized as very effective. Only in 2016 that the effectiveness level was categorized as quite effective. In this basis, it is necessary to note how the policy to set the 
target is implemented because based on the table above, the target in 2015 and 2017 is always below the revenue realization from the previous year. In 2014, the realization was IDR $1,365,866,946$ while the next year's target was reported to be IDR 1,305,000,000. In 2015 , the realization was IDR 5,697,844,110 while the target in 2016 was IDR $1,305,000,000$. Then, in 2017 , the target was recorded to be IDR $1,710,581,000$ while the previous year's realization was IDR $1,720,062,899$. This data shows that the target of the revenue from agility games is lower than the realization of the previous year although, in 2016, the target set was higher than the realization in 2015.

Based on the above explanation, it is important to take a look at the policy which determines the target of revenue, especially in the tourism sector. The Regional Finance Agency of Batu City needs to make an analysis of the tax revenue potential given the importance of making a comprehensive and more realistic budget planning. The analysis of revenue potential aims to find out the opportunities for optimal revenue that can still be realized. In this matter, the tax potential is still hidden so that it is necessary to examine the amount of potential revenue that exists. Local government needs to recognize their regional revenue potential. In the next point, a potential analysis will be presented.

The Analysis of Entertainment Tax Potential. The optimization of the entertainment tax revenue of Batu City in the tourism sector can be known by analyzing the potential first. To find out the potential for entertainment tax in the tourism or recreation sector, the general data and analysis of entertainment classifications are needed both from changes in tax rates, the number of Batu City tourism objects in 2017, the price of admission, and the number of visits. The first analysis can be done by looking at the entertainment tax rate comparison.

Table 6 - The Percentage Comparison of Entertainment Tax in Each Sector According to Regional Regulation number 6 of 2010 and Regional Regulation number 2 of 2012

(Changes to Entertainment Tax)

\begin{tabular}{|c|l|c|c|c|}
\hline Number. & Types of Entertainment Tax & 2010 & 2012 & Status (Down) \\
\hline 1 & Movies/Cinemas & $35 \%$ & $10 \%$ & $25 \%$ \\
\hline 2 & Music, dance, and/or fashion & $35 \%$ & $10 \%$ & $25 \%$ \\
\hline 3 & $\begin{array}{l}\text { Creative traditional art that is protected } \\
\text { and preserved }\end{array}$ & $10 \%$ & $5 \%$ & $5 \%$ \\
\hline 4 & Beauty contest, body building & $35 \%$ & $10 \%$ & $25 \%$ \\
\hline 5 & $\begin{array}{l}\text { exhibition of computers, electronics, } \\
\text { automotive, fashion, artificial tourist } \\
\text { parks, and etc }\end{array}$ & $35 \%$ & $10 \%$ & $25 \%$ \\
\hline 6 & $\begin{array}{l}\text { Educational exhibitions such as parks } \\
\text { that introduce or demonstrate the } \\
\text { knowledge about animals, plants, and } \\
\text { culture as well as museums or galleries }\end{array}$ & $35 \%$ & $7,5 \%$ & $28 \%$ \\
\hline 7 & Karaoke, nightclub, and etc & $\begin{array}{l}\text { Karaoke 35\%, } \\
\text { Nightclub 75\% }\end{array}$ & $25 \%$ & $\begin{array}{l}\text { Karaoke } 10 \%, \\
\text { Nightclub } 50 \%\end{array}$ \\
\hline 8 & Circus, acrobatics, magic, and etc & $35 \%$ & $10 \%$ & $25 \%$ \\
\hline 9 & Pool & $35 \%$ & $20 \%$ & $15 \%$ \\
\hline 10 & Golf and Bowling & $35 \%$ & $25 \%$ & $10 \%$ \\
\hline 11 & $\begin{array}{l}\text { Other sports games such as mini } \\
\text { soccer games and etc }\end{array}$ & $15 \%$ & $10 \%$ & $5 \%$ \\
\hline 12 & Horse race, motor race, agility game & $\begin{array}{l}\text { Horse and motor } \\
\text { race 35\%, agility } \\
\text { games } 75 \%\end{array}$ & $10 \%$ & $\begin{array}{l}\text { Horse and motor } \\
\text { race } 25 \%, \text { agility } \\
\text { games } 65 \%\end{array}$ \\
\hline 13 & & $75 \%$ & $25 \%$ & $50 \%$ \\
\hline 15 & Massage parlor, reflection, and steam & & $10 \%$ & $25 \%$ \\
\hline & Fath/spa & $35 \%$ & $15 \%$ & $5 \%$ \\
\hline
\end{tabular}

This is regulated in the Batu City Regional Regulation number 6 of 2010 concerning Entertainment Tax which has been stipulated and promulgated in the Batu City Regional Gazette in 2010 number 5/B. Whereas, Entertainment Tax is a potential source of PAD in which the amount of revenue from this sector is not solely for a development in one sector but also other sectors. 
Eurasia: Economics \& Business, 7(13), July 2018

DOI https://doi.org/10.18551/econeurasia.2018-07

Table 7 - The Calculation of Entertainment Tax Potential on the Management of Recreational Park in Batu City, 2017

\begin{tabular}{|c|c|c|c|c|c|c|c|c|}
\hline \multirow[t]{2}{*}{ № } & \multirow[t]{2}{*}{ NAME } & \multirow[t]{2}{*}{ TYPES } & \multicolumn{2}{|c|}{ TICKET PRICE } & \multicolumn{2}{|c|}{ VISIT LEVEL } & \multirow{2}{*}{$\begin{array}{c}\text { TAX } \\
\text { RATES }\end{array}$} & \multirow[t]{2}{*}{ TOTAL } \\
\hline & & & WEEKDAY & WEEKEND & WEEKDAY & WEEKEND & & \\
\hline 1 & Jawa Timur Park 1 & Integrated Tourism Object & $\mathrm{Rp} 70,000$ & IDR100,000 & 133,450 & 88,967 & $10 \%$ & IDR1,823,819,400 \\
\hline 2 & Batu Wonderland Water Park & Water Tour & IDR10,000 & IDR30,000 & 2,782 & 1,854 & $10 \%$ & IDR,.344,800 \\
\hline 3 & Museum Satwa & Integrated Tourism Object & \multirow[t]{2}{*}{ IDR84,000 } & \multirow[t]{2}{*}{ IDR120,000 } & \multirow[t]{2}{*}{213,715} & \multirow[t]{2}{*}{142,476} & \multirow[t]{2}{*}{$7.5 \%$} & \multirow[t]{2}{*}{ IDR2,628,689,580 } \\
\hline 4 & Batu Secret Zoo & Integrated Tourism Object & & & & & & \\
\hline 5 & Eco Green Park & Educational Tour & IDR49,000 & IDR70,000 & 60,840 & 40,560 & $7.5 \%$ & IDR436,527,000 \\
\hline 6 & Batu Night Spectaculer(BNS) & Integrated Tourism Object & IDR30,000 & IDR40,000 & 138,001 & 92,001 & $10 \%$ & IDR782,006,800 \\
\hline 7 & Coban Rais & Ecotourism & IDR10,000 & IDR10,000 & 75,056 & 50,037 & $10 \%$ & IDR125,093,000 \\
\hline 8 & Wisata Berkuda Mega Star & Adventurous Tour & IDR25,000 & IDR25,000 & 7,570 & 5,046 & $10 \%$ & IDR31,540,000 \\
\hline 9 & Batu Flower Garden & Integrated Tourism Object & IDR25,000 & IDR25,000 & 9,000 & 6,000 & $10 \%$ & IDR37,500,000 \\
\hline 10 & Tirta Nirwana Songgoriti & Water Tour & IDR15,000 & IDR15,000 & 10,368 & 6,912 & $10 \%$ & IDR25,920,000 \\
\hline 11 & $\begin{array}{l}\text { Pemandian Air Panas Alam } \\
\text { Songgoriti }\end{array}$ & Natural Hot Springs & IDR20,000 & IDR25,000 & 11,253 & 7,502 & $10 \%$ & IDR41,261,000 \\
\hline 12 & Paralayang Gunung Banyak & Adventurous Tour & IDR10,000 & IDR15,000 & 2,480 & 1,653 & $10 \%$ & IDR4,959,600 \\
\hline 13 & Kusuma Agro Water Park & Integrated Tourism Object & IDR25,000 & IDR30,000 & 107,721 & 71,814 & $10 \%$ & IDR484,744,500 \\
\hline 14 & Museum Angkut & Integrated Tourism Object & IDR70,000 & IDR100,000 & 190,483 & 126,989 & $10 \%$ & IDR2,603,270,400 \\
\hline 15 & Kusuma Agro Wisata & Adventurous Tour & IDR65,000 & IDR70,000 & 126,658 & 84,438 & $10 \%$ & IDR1,414,343,200 \\
\hline 16 & Coban Talun & Waterfall & IDR10,000 & IDR10,000 & 38,511 & 25,674 & $10 \%$ & IDR64,185,000 \\
\hline 17 & Selecta & Integrated Tourism Object & IDR35,000 & IDR35,000 & 730,367 & 486,911 & $10 \%$ & IDR4,260,473,000 \\
\hline 18 & Taman Langit(Gunung Banyak) & Integrated Tourism Object & IDR10,000 & IDR10,000 & 74,584 & 49,722 & $10 \%$ & IDR124,306,000 \\
\hline 19 & Pemandian Air Panas Cangar & Natural Hot Springs & IDR10,500 & IDR10,500 & 126,733 & 84,488 & $10 \%$ & IDR221,782,050 \\
\hline 20 & Kampoeng Kidz & Educational Tour & IDR20,000 & IDR20,000 & 5,742 & 3,828 & $7.5 \%$ & IDR14,355,000 \\
\hline 21 & Kaliwatu Rafting & Adventurous/Pack Tour & IDR150,000 & IDR150,000 & 5,731 & 3,821 & $10 \%$ & IDR143,280,000 \\
\hline 22 & Sahabat Air Rafting Outbound & Adventurous Tour & IDR200,000 & IDR200,000 & 950 & 634 & $10 \%$ & IDR31,680.,00 \\
\hline 23 & Predator Fun Park & Integrated Tourism Object & IDR35,000 & IDR50,000 & 94,976 & 63,318 & $10 \%$ & IDR649,005,400 \\
\hline 24 & Jawa Timur Park 3 & Integrated Tourism Object (per 2 rides) & IDR170,000 & IDR170,000 & 15,000 & 10,000 & $10 \%$ & IDR425,000.,00 \\
\hline 25 & Kampung wisata kungkuk & - & IDR65,000 & IDR65,000 & 8,194 & 5,462 & $10 \%$ & IDR88,764,000 \\
\hline 26 & Petik Apel Mandiri & - & IDR25,000 & IDR25,000 & 4,991 & 3,327 & $10 \%$ & IDR133,088,000 \\
\hline 27 & Petik Apel "Makmur Abadi" & - & IDR25,000 & IDR25,000 & 15,826 & 10,550 & $10 \%$ & IDR422,016,000 \\
\hline & & Total & & & & & & IDR17,025,953,730 \\
\hline
\end{tabular}


In the implementation, several provisions in the referred Regional Regulation have some constraints, especially in terms of imposing tax rates. In order to fulfill the aspirations of the community and to smooth the entertainment tax collection, it is necessary to amend the Batu City Regional Regulation number 6 of 2010 concerning the Entertainment Tax.

As seen from the table above, it can be explained that the entertainment tax rate as a whole experienced a significant decline ranging from $5 \%$ to $65 \%$. The agility game is one of the entertainment tax objects which experienced a decrease from $75 \%$ to $10 \%$. Massage parlors, reflections, and steam baths/spas also known to be decreased from $75 \%$ to $25 \%$. The tax rates for nightclubs have a decline that is from $75 \%$ to $25 \%$ whereas educational exhibitions such as parks that introduce or demonstrate knowledge about animals, plants, and culture as well as museums or galleries also fell from $35 \%$ to $7.5 \%$. It is also revealed that the entertainment tax rate for fitness center is also down from $35 \%$ to $10 \%$.

This reduction is one of the strategies of the Regional Finance Agency of Batu City to reduce the level of entertainment tax leakage, especially in terms of tourist attractions. This tariff reduction policy is based on the aspirations of the community so that taxpayers are expected to voluntarily pay the entertainment tax objects. However, it should also be noted that the potential lost due to tariff reduction because some entertainment tax objects are dropped quite dramatically reaching $65 \%$. One potential object that experienced a significant reduction in tax rates was the agility game. In this basis, researchers felt that the Regional Finance Agency of Batu City needs to review the tax function as revenue or budget in specific. Moreover, there is a great chance to change Batu City's entertainment tax regulation which has been running for 6 years by adjusting to the economic conditions, benchmarking tax rates with cities that have similar characteristics (as a tourism city), and also considering the tax aspect as a regulatory function. This can be seen from the tax rate reduction policy, especially regarding night entertainment objects which have a high negative impact and tends to damage the morale of the younger generation. It is expected to consider one of the regulatory aspects by raising the tax rate for objects that have a high negative impact as well as the objects that have great potential of revenue for Batu City. The following table displays the calculation of the potential for entertainment tax on the management of recreational entertainment in Batu City.

Based on the calculation of entertainment tax potential on the management of recreational park in Batu City by IDR17,025,953,730,00,- it can be said that the potential for entertainment tax in the recreational park management in Batu City (2017) is greater than the realization of tax revenue in the recreation sector that is IDR $14,026,556,036,00,-\mathrm{A}$ margin by IDR2,999,397,694,00,- is also generated but only it cannot or has not been collected by the Regional Finance Agency of Batu City. To realize all these potentials, local government needs to raise the awareness of the taxpayers. In addition, due to the vast potential caused by many factors that influence the revenue, it is necessary to identify tax objects more specifically in order to be able to see the real potential.

\section{CONCLUSION}

The collection system of Entertainment Tax in Batu City is conducted by using the selfassessment system. This system explains that taxpayers are given the trust to calculate, pay, and deposit their own tax obligations. This system requires an active role of the taxpayers and also the supervisory role of the tax authorities. Furthermore, one measure of regional revenue administration is to calculate the level of effectiveness or tax effectivity. On average, the entertainment tax can be said to be effective because the revenue realization is $108.62 \%$ or is greater than the target set.

The calculation of entertainment tax potential for the management of recreational park in Batu City is IDR $17,025,953,730,00,-$. This means that the entertainment tax potential for the management of recreational park in Batu City (2017) is greater than the realization of revenue tax in recreation sector that is IDR 14,026,556,036,00,-. A margin of IDR $2,999,397,694,00,-$ is processed meaning that this number is actually existed but has not been collected by the Regional Finance Agency of Batu City. 


\section{SUGGESTIONS}

It is suggested to make an analysis of potential tax revenue in the establishment of revenue target, especially in the tourism sector. The Regional Finance Agency of Batu City needs to plan a comprehensive and realistic budget. The analysis of revenue potential aims to find out the opportunity for optimal income that can still be realized.

The local government needs to raise the awareness of the taxpayers. In addition, due to the vast potential caused by many factors that influence the tax revenue, tax effort is needed by identifying tax objects in a more specific manner to make the real potential visible.

\section{REFERENCES}

1. Anggoro, D. D. (2017). Pajak Daerah dan Retribusi Daerah. Malang: Universitas Brawijaya Press.

2. Bahl, R., \& Smoke, P. (2003). Restructuring Local Government Finance in Developing Countries: Lesson from South Africa. USA: Edward Elgar Publishing Inc.

3. Batu City Regional Regulation number 6 of 2010 concerning Entertainment Tax.

4. Batu City Regional Regulation number 2 of 2012 concerning Amendment to Entertainment Tax.

5. Devas, N., et al. (1989). Keuangan Pemerintah Daerah Di Indonesia (1st Ed). Jakarta: Penerbit Universitas Indonesia.

6. Law of the Republic of Indonesia number 28 of 2009 concerning Regional Taxes and Regional Retributions

7. Mahmudi. (2010). Manajemen Keuangan Daerah. Jakarta: Erlangga.

8. Regional Statistics of Batu City. 2017. Central Bureau of Statistics. Batu City

9. Solarno, S. (1999). Pajak Daerah dan Retribusi. Jakarta: STIA-LAN. 